\title{
THE ANALYSIS OF THE DEGREE OF FLOOD RISK IN THE MIDDLE BOBR VALLEY
}

\author{
Magda HUDAK, Urszula KOŁODZIEJCZYK, Jakub KOSTECKI ${ }^{1}$, \\ Ireneusz NOWOGONSKI, Marta ŻEBROWSKA \\ University of Zielona Gora, Zielona Góra, Poland
}

\begin{abstract}
This paper presents the impact of rainfall on the degree of flood risk in the basin of the middle Bobr River in western Poland. When the average rainfall level reaches 15 to 20 $\mathrm{mm}$, this apparently calm river may dramatically change its character within just one week. The most important flood risks are flood waves in the headwaters. Because of the mountain character of the river basin, during intensive rainfall there is a huge surface runoff and the water level rises rapidly in the river. This phenomenon was observed in June 2017 in the town of Zagan (Lubuskie Voivodeship).

It has been shown that the course and dynamics of hydrological processes occurring in the Bobr River basin depend on its physical and geographical characteristics and the influence of anthropogenic factors. The location is one of the main cause of numerous floods for Zagan, on the other hand changes in land development plays significant meaning in flood hazards. Continuous monitoring of the river is the basis for a comprehensive forecast of flood risks.
\end{abstract}

Keywords: flood risk, valley of the Bobr River, flood in Poland

\section{INTRODUCTION}

Flooding is one of the most common natural hazards in river valleys. Dynamic transformations of the valley landform, which may occur during floods, are

${ }^{1}$ Corresponding author: University of Zielona Góra; Institute of Environmental Engineering, Szafrana s 15, 65-516 Zielona Góra, Poland, j.kostecki@iis.uz.zgora.pl 
regarded as natural hazards [10]. The level of flood risk in the Bobr River valley is determined by natural factors, such as landform, soil, geological structure, vegetation, precipitation intensity, the surface area and landform of the river basin, as well as anthropogenic factors such as river bed regulation, hydrotechnical infrastructure and development of the valley [15]. Specific floodwater accumulation on the Bobr River is caused by intensive and longlasting rainfall and the discharge of water from the storage reservoirs in the river's headwaters.

Assessment of flood hazard is one of the most discussed problem of modern world $[6,21]$. This is related to the urbanization and usage of areas that were previously not taken into account in terms of land development [3, 22]. In global terms, the effects of climate change - uneven precipitation, local droughts, heavy rainfall and flooding in selected city districts - are easily visible.

Among the solutions to protect cities against flooding the most popular are classic solutions such as flood embankments and wet and dry polders, however more strategic documents are being developed such as plans for adaptation to climate change $[18,19]$.

In terms of flood protection, it is possible to say clearly that in some segments the condition of the inter-levee area is far from perfect, and the area with thick vegetation contributes to reducing the flow capacity and results in raising the water level in the river bed $[11,23]$.

\section{MATERIALS AND METHODS}

\subsection{Characteristics of the research area}

The town of Zagan, the medium size city, is located in the south-western part of Poland (51 $37^{\prime} 03^{\prime}$ N , 15 $18^{\circ}$ '53'E), in the valley of the middle Bobr River - a leftbank tributary to the Oder River (Fig. 1). The terrain is varied here. The highest elevations (134 $\mathrm{m}$ a. s. 1.) are located in the north-eastern part of the town, in the western part they range from 100 to $115 \mathrm{~m}$ a. s. 1., and in the south - from 115 to $120 \mathrm{~m}$ a. s. 1. The terrain gradually becomes lower towards the north and northwest along the Bobr River (down to $92 \mathrm{~m}$ a. s. 1.) where it forms a valley of about $40 \mathrm{~km}^{2}$.

According to the physical and geographical regionalization of Poland, the town of Zagan belongs to the macroregion of the Silesian-Lusatian Lowlands, the mesoregion of Bory Dolnośląskie and the microregion of Kotlina Zaganska. The numerous forest areas and dense hydrographic network make the entire area of the town interesting in terms of landscape.

This area is located on the border of two climatic regions: Silesian-Greater Poland and the Sudetes. The Zagan region, as well as the whole western part of Poland, 
has a transitional climate with a clear dominance of the oceanic climate, which makes winters mild and summers warmer with high precipitation levels. An important feature of this type of climate is high variability in temperature and humidity, which are strongly connected to one another. This variability is the highest in the late autumn and winter. For this reason, fog often occurs in these periods, and it lasts long in daytime because of the location of Zagan in the valley and water evaporating from the Bobr River. An important component of the climate in this area is precipitation. Its annual level is $600-700 \mathrm{~mm}$. According to data from the Institute of Meteorology and Water Management in Wroclaw, the highest precipitation levels occur during spring and summer, i.e. from May to August. However the average number of days with precipitation vary from 8 to 12. Wind from the west, north-west and south-west clearly prevails in this area. Average temperature for Zagan over a 35-year period is showed in Fig. 1.

The Bobr River is a mountain-lowland river flowing from the south to the north. The riverhead is located in the Karkonosze Mountains, $2.5 \mathrm{~km}$ into the Czech Republic, at $864 \mathrm{~m}$. above sea level. The name "Bobr" comes from the name of the village from which the river originates [16]. From the riverhead to the area of Krosno Odrzańskie where the river flows into the Odra River, the Bobr River has a length of $268 \mathrm{~km}$. It is the fourth longest tributary of the Oder River.

The Bobr River basin covers an area of $5938 \mathrm{~km}^{2}$ and the sub-basin in Zagan $4254.0 \mathrm{~km}^{2}$. The water regime of the Bobr River is mainly influenced by snow and rain. The water level in all smaller rivers and streams depends on the water level in the Bobr River. Annual fluctuations of the water level in the Bobr River reflect spring and summer high water. Spring high water is due to the discharge of melt-water. In most cases it occurs in March and April, but when the winter is short, it can also occur in January or February, and when the winter is long - it can even last until May. Summer high water is caused by heavy and continuous precipitation occurring mostly in July. Summer high water usually lasts shorter and is more regular. Low water levels usually occur on the Bobr River in midJuly and last until the end of August. They are mainly a result of long-lasting draughts caused by stable dry and hot weather. Winter low water mostly occurs when the weather is dry with sub-zero temperatures.

\subsection{Research methodology}

In order to analyse the degree of flood risk in Zagan, regular surveys of water gauges were conducted on the Bobr River in Zagan (Photo 1) during high water at the turn of May and June 2017.

The Zagan water gauge station is located on $\mathrm{km} 75+880$ of the Bobr River. The average water level is $200 \mathrm{~cm}$, the warning level is $340 \mathrm{~cm}$, and the alarm level is $400 \mathrm{~cm}$. The zero ordinate of the Zagan water gauge is defined in relation to the 
national levelling network at 91,914 $\mathrm{m}$ a.s.l. Readings were recorded from the watermark twice a day - at 6.00 and 18.00 UTC, from 25 May to 30 June 2017. In the Zagan region the hydrological regime of the Bobr River is changed due to the influence of water management in reservoirs located in the river headwaters as well as aggregate mining [5]. The river is partly regulated and has a slightly meandering character. The largest left-bank tributary to the Bobr River here is the Czerna Wielka River with its left-bank tributary the Złota Struga River. The rightbank tributaries to the Bobr River are numerous nameless streams. In terms of ecological status, the water of the Bobr River is considered to be good. In the vast valley of the river bed, the width of which varies from 2 to $3 \mathrm{~km}$, it is possible to distinguish: the normal river bed, the flood river bed and the floodplains. The average width of the Bobr River bed is $50 \mathrm{~m}$, the depth varies from $0.2 \mathrm{~m}$ to 2.5 $\mathrm{m}$, on average (with the normal water level) it reaches about $1.5 \mathrm{~m}$. The course of the river bed is curved, with several straight sections. The longitudinal profile of the river is balanced - the greatest difference in the Zagan region ranges from $95.00 \mathrm{~m}$ to $94.53 \mathrm{~m}$.

The average annual flow is $39.3 \mathrm{~m}^{3} / \mathrm{s}$. The river is partly regulated and has a slightly meandering character. The highly meandering Czerna Wielka River flows along the western perimeters of the town and into the Bobr River in the northern part of Zagan $(\mathrm{km} 63+600)$. The flood risk in the Zagan region is very high and reaches 0.95 . According to the Institute of Meteorology and Water Management in Wroclaw, the highest water level $(796 \mathrm{~cm})$ was recorded in Zagan in 1897 [16]. However, in the previous century, similarly high water levels in the Bobr River (significantly above the $400 \mathrm{~cm}$ alarm level) were observed in 1958, 1977, 1981 and 1997. In some periods higher water levels occurred every 1-2 years and every 4-5 years. Between 1985 and 1995, no significantly high water levels occurred in the Bobr River basin. After a 10-year break, in the years 1995-1997 there were another 3 high water levels at one-year intervals, the highest of which $(705 \mathrm{~cm})$ occurred in 1997. [15]. By 2013, the situation was very similar; high water levels occurred every 2-4 years. The analysis shows that the waters of the Bobr River exceeded the alarm level 26 times in 68 years, and the average frequency of exceeding the alarm level was from 3 to 5 years (Fig. 2).

The town of Zagan is protected by class III levees on both sides of the Bobr River. The total length of the levees is $4287 \mathrm{~m}$ : on the right bank $1390 \mathrm{~m}$ and on the left bank $2897 \mathrm{~m}$ (Fig. 3-5). They are built of made ground consisting of sandy, clayey, low-compacted soil (ID $=0.34-0.45$ ).

\section{RESULTS AND DISCUSSION}

Before high water on the Bobr River in May 2013 the weather conditions in the area were determined by a vast and vertically extended low, in which two centres 
appeared quickly - over the Czech Republic and over Germany. The total precipitation in the month of June ranged from 100 to $180 \mathrm{~mm}$. In Lower Silesia and in the Lubusz Voivodship 3 flood risk warnings were announced. The Bobr River exceeded the alarm level and the warning level in all water gauge profiles. This situation continued for 5 weeks, and had been caused by continuous heavy rainfall in southwestern Poland.

According to the information provided by the Regional Water Management Board in Wroclaw, the water level in the Zagan water gauge section was around the alarm level from 27 May to 15 June and from 26 to 30 June. The peak of the flood wave occurred on 6 June at 6.00 UTC - at its highest point it reached $604 \mathrm{~cm}$ (Fig. 4).

In the south of Poland and in Zagan as well, the total rainfall exceeded $150 \mathrm{~mm}$ (Table 1), which led to an increase in the water level also in the tributaries to the middle Bobr River - mainly in the Kwisa River. The flow of the rainfall water was slow and long lasting. The flood wave was similar in character. The rise of the water level was sudden and rapid and the fall was slow.

The rainfall that occurred in the second half of the month and the discharge of water from the storage reservoir in Leśna caused a further rise in the water level and resulted in exceeding alarm levels on Bobr River (Fig. 4).

Due to the hydrological situation in the region there was a flood alert. The high water level did not cause any major damage, but the town boulevard and the cycle lane were flooded as well as some of the streets: Dworcowa, Pstrowskiego and Księżna Żaganna (Photo 2). An extensive area of the Bobr River valley in the northern part of the town was also flooded.

From the results shown above, it could be seen that the precipitation is not evenly distributed over the whole studied area and the water level in the Bobr river bed is very changeable. In recent years the river reached its highest water level in 2013 $(604 \mathrm{~cm})$ and the lowest - in $2015(180 \mathrm{~cm})$. Flooding is a significant challenge for many societies. From the year of 1900 nearly $30 \%$ of all natural disasters in the world were floods [1]. Recent research shows the frequency of flood events appears to be on the rise [1,17]. Jenkins et al [13] that this may be caused by climate change and increasing urbanization which result in an increase in surface water flooding and consequential damages in the future.

Buzin [4] said, that one of the most important problems of social and economical stability of every country is the readiness of its structures to resist the dangerous weather phenomena. To counteract the causes and consequences of floods, the EU developed the Floods Directive [7]. It seeks to reduce the adverse consequences for human health, the environment, cultural heritage and economic activity associated with floods. It is designed in 3 steps: preliminary assessment of risk, the preparation of flood hazard and flood risk maps and the design of flood 
risk management plans. Some of the proposed solutions are reflected in scientific works $[2,12,20]$.

\section{CONCLUSIONS}

The location of Zagan in the valley of the Bobr River is the cause of numerous floods, which makes intensive flood protection in the town necessary. Especially dangerous are high water levels in the headwaters of the Bobr River, where precipitation often exceeds $1000 \mathrm{~mm}$ per year. The system of storage reservoirs located in the headwaters of the Bobr River (in Pilchowice) and the Kwisa River (in Lesna) has a significant impact on the town's flood protection. Eeffective management of surface water flood risk is critical to ensure that the regions such as valley of the Bobr River can mitigate and adapt for future floods in a cost effective manner.

The course and dynamics of hydrological processes occurring in the Bobr River basin depend on its physical and geographical characteristics and the influence of anthropogenic factors, the most important of which are changes in land development.

Monitoring of the river is the basis for a comprehensive forecast of flood risks. Verification of fluvial processes occurring on the river bed as a result of flood waters may improve the effectiveness of flood protection in the town. This directive is transposed in Polish Law via Water Law Act [8], however not all the solutions are yet reflected in reality.

\section{REFERENCES}

1. Adikari Y., Yoshitani J.: Global trend in water-related disasters - an insight for policymakers. Paris: UNESCO; 2009.

2. Alexander M., Priest S., Mees H.: A framework for evaluating flood risk governance, in: Environmental Science \& Policy, 64 (2016), 38-47.

3. Bielecka E., Ciołkosz A.: Flood susceptibility of the Odra valley; its relation to land use changes. Archiwum Fotogrametrii, Kartografii i Teledetekcji, 10 (2000), 26.1-26.8

4. Buzin V.A. Formation factors and forecast of ice dams on rivers of the north of the European territory of Russia, in: Russian Meteorology and Hydrology, 35, 4 (2010), 272-280.

5. Chrzan, T.: The utilization rate of the natural aggregate deposit extracted from the Bóbr River sediments, in: Raw materials and construction equipment, 5 (2008), 41-44 [in Polish].

6. Dewan A.M., Monirul M., Kumamoto I.T., Nishigaki M.: Evaluating Flood Hazard for Land-Use Planning in Greater Dhaka of Bangladesh Using 
Remote Sensing and GIS Techniques, Water Resources Management 21, 9 (2007), 1601-1612.

7. Directive 2007/60/EC of the European Parliament and of the Council of 23 October 2007 on the assessment and management of flood risks.

8. Dz.U. 2017 poz. 1566. Act of 20 July 2017 Water Law.

9. ECAD - European Climate Assessment \& Dataset, http://eca.knmi.nl/.

10. Gares P.A., Sherman D.J., Nordstrom K.F.: Geomorphology and natural hazards, in: Geomorphology, 10 (1994), 1-18

11. Głosińska E.: Floodplain management in the context of assessment and changes of flood risk and the environment - a review, in: Polish Journal of Environmental Studies, 23, 6 (2014), 1895-1904.

12. Green C.: Towards sustainable flood risk management, in: International Journal of Disaster Risk Science, 1, 1 (2010), 33-43.

13. Jenkins K., Surminski S., Hall J., Crick F.: Assessing surface water flood risk and management strategies under future climate change: Insights from an Agent-Based Model, in: Science of the Total Environment. 595 (2017), 159168.

14. Kołodziejczyk, U.: The contribution of anthropogenic factor in the formation of the flood wave, in: Scientific Papers of the University of Zielona Góra, Series: Civil Engineering, 130 (2003), 37-45 [in Polish].

15. Kołodziejczyk U., Kuroczycki L., Żebrowska M.: Floods on the Bóbr River in Żagan in the light of historical observations, in: Scientific Papers of the University of Zielona Góra, Series: Environmental Engineering, 162, 42 (2016), 129-137 [in Polish].

16. Mirski, Z.: Żagań. Lubuskie notes. Lubuskie Society of Culture in Zielona Góra, 1981 [in Polish].

17. Schanze J.: Flood risk management - a basic framework, in: Schanze J, Zeman E, Marsalek J, ed. Flood risk management — hazards, vulnerability and mitigation measures. Springer; 2006.

18. Strategic adaptation plan for sectors and areas sensitive to climate change by 2020 with a perspective up to 2030, Ministry of the Environment, Warsaw 2013, p. 60 [in Polish].

19. Tokarczyk-Dorociak K., Walter E., Kobierska K., Kołodyński R. Rainwater Management in the Urban Landscape of Wroclaw in Terms of Adaptation to Climate Changes. Journal of Ecological Engineering, 18, 6 (2017), 171-184.

20. Verbitskaya E. M., Ageeva S. V., Dugina I. O., Dunaeva I. M., Efremova N. F., Romanskii S. O., Tarasyuk V. V.: Catastrophic Flood on the Amur River in Summer 2013: Features and Causes, in: Russian Meteorology and Hydrology, 40, 10 (2015), 683-690. 
21. Vorogushyn S., Merz B., Lindenschmidt K.E., Apel H.: A new methodology for flood hazard assessment considering dike breaches. Water resources research 48, 8 (2010), 1-17.

22. Walczykiewicz T., Biedron I.: Development of river valleys in the light of flood risk management, [in:] Legal, administrative and environmental conditions for the development of river valleys, ed. B. Więzik, Wyższa Szkoła Administracji w Bielsku Białej, Bielsko Biała 2013, p. 146 [in Polish].

23. Wiatkowski M., Rosik-Dulewska C., Tymiński T.: Analysis of water management of the michalice reservoir in relation to its functions, in: Ecological Chemistry and Engineering. A. 17, 11 (2010), 1505-1516.

\section{ANALIZA STOPNIA ZAGROŻENIA POWODZIOWEGO W DOLINIE ŚRODKOWEGO BOBRU}

\section{Streszczenie}

W artykule przedstawiono wpływ natężenia opadów atmosferycznych na stopień zagrożenia powodziowego w dorzeczu środkowego Bobru. Ta na pozór spokojnie płynąca rzeka, w ciągu zaledwie tygodnia, przy średnim opadzie 15-50 mm, może diametralnie zmienić swój charakter. Największe zagrożenie powodziowe stanowią wezbrania powodziowe wystepujace w górnym biegu rzeki. Z uwagi na górski charakter dorzecza, podczas występowania opadów o znacznym natężeniu obserwowane są duże spływy powierzchniowe, co prowadzi do gwałtownego przyboru wody w rzece. Zjawisko takie zarejestrowano w czerwcu 2013 r. w Żaganiu.

W pracy wskazano, że przebieg i dynamika procesów hydrologicznych zachodzących w dorzeczu Bobru zależą od jego cech fizycznych i geograficznych oraz od wpływu czynników antropogenicznych. Jako główną przyczynę powodzi wskazano lokalizację miasta; istotne znaczenie w zagrożeniu powodziowym ma również zagospodarowanie terenu. Podstawą kompleksowej ochrony przeciwpowodziowej jest więc ciągły monitoring rzeki.

Słowa kluczowe: $\quad$ zagrożenie powodziowe, dolina rzeki Bóbr

Editor received the manuscript: 15.02.2018 